\title{
METABOLIC ENERGY IS REQUIRED IN HUMAN PLATELETS AT ANY STAGE DURING OPTICAL AGGREGATION AND SECRETION
}

\author{
ADRIE J.M. VERHOEVEN, MARLĖNE E. MOMMERSTEEG and JAN-WILLEM N. AKKERMAN * \\ Department of Haematology, University Hospital Utrecht, P.O. Box 16250, 3500 CG Utrecht (The Netherlands)
}

(Received February 9th, 1984)

Key words: Platelet aggregation; Energy content; Secretion; (Human)

The relationship between metabolic energy and platelet aggregation and secretion was investigated by sudden exhaustion of the cell energy content after these platelet responses had been initiated. In normal platelets, optical aggregation was at any stage susceptible to energy exhaustion, whereas single platelet disappearance and secretion were hardly affected. Prelowering the platelet energy content, while preserving the adenylate energy charge, made both optical aggregation and the secretion from dense, $\alpha$ - and acid hydrolase-containing granules susceptible to energy exhaustion, but single platelet disappearance was not affected. Complete arrest of secretion occurred when the energy content had fallen below 3-3.5 $\mu \mathrm{mol}$ ATP equivalents (ATPeq) $/ 1^{11}$ platelets, while optical aggregation was interrupted below 2-2.5 $\mu \mathrm{mol}$ ATPeq $/ 10^{11}$ platelets. At any stage of optical aggregation and the three secretion responses, the dependence on energy remained the same, indicating a tight coupling between these functions and metabolic energy, which held during the entire responses.

\section{Introduction}

The widely held concept that platelet responses require metabolic energy is based mainly on two observations. First, platelet stimulation is accompanied by an increase in aerobic and anaerobic energy metabolism and a fall in metabolic ATP [1-4]. Second, induction of metabolic blockade prior to stimulation abolishes all responses [3,5-9]. Both findings appear to be in favour of a close connection between cellular responses and energy metabolism, but a number of observations argue against a direct relationship. The burst in mitochondrial $\mathrm{O}_{2}$ uptake is late and not seen with weak stimulators $[4,10]$. On the other hand, the increase in glycolytic flux is immediate, but lactate formation remains high long after aggregation and secretion are completed $[1,4,11]$. Hence, the possi-

\footnotetext{
* To whom correspondence should be addressed.
}

bility remains that these metabolic changes do not take part in the execution of platelet responses and merely reflect repair processes that help the platelets to recover $[11,12]$.

Likewise, experiments with metabolic inhibitors are inconclusive. Most inhibitors act slowly, and incubation times of up to $20 \mathrm{~min}$ are required for complete depletion of the cell energy content $[7,9,13]$. Consequently, they can not be applied during rapid processes, such as aggregation and secretion, which are completed within 1-2 min following stimulation with strong agonists. Preincubation of resting platelets with metabolic inhibitors, however, leads to a fall in responsiveness, and it has been argued that such a treatment already severely damages the platelets before the cellular responses are initiated $[3,11]$.

Recently, we have developed a technique for inducing sudden blockade of ATP resynthesis [14]. This leads to an immediate fall of metabolic ATP 
and ADP, thereby exhausting most of the cells' rapidly accessible energy within about $45 \mathrm{~s}$. In the present report, we have used this technique to evaluate the energetics of aggregation and secretion in platelets that were optimally responsive during induction of these processes.

\section{Materials and Methods}

\section{Platelet isolation}

Freshly drawn venous blood was collected from healthy human volunteers into citrate $(0.1 \mathrm{vol}$. of $129 \mathrm{mM}$ sodium citrate). After centrifugation (200 $\times g, 10 \mathrm{~min}$, room temperature) the supernatant, platelet-rich plasma, was incubated with $1 \mu \mathrm{M}$ 5 -hydroxy $\left[\beta^{-14} \mathrm{C}\right]$ tryptamine $\left(\left[{ }^{14} \mathrm{C}\right]\right.$ serotonin, spec. act. $58 \mathrm{Ci} \cdot \mathrm{mol}^{-1}$, Amersham International, U.K.) and $1 \mu \mathrm{M}\left[2{ }^{3} \mathrm{H}\right]$ adenine (spec. act. $3 \mathrm{Ci} \cdot \mathrm{mmol}^{-1}$, Amersham International, U.K.), for $45 \mathrm{~min}$ at $37^{\circ} \mathrm{C}$ to label the serotonin in the dense granules and the metabolic pool of adenine nucleotides, respectively (in contrast to non-metabolic, granular ATP and ADP). The platelets were then isolated by gel filtration at room temperature on Sepharose 2B (Pharmacia, column size $5 \times 20 \mathrm{~cm}$ ), equilibrated in $\mathrm{Ca}^{2+}$-free Tyrode's solution containing $1 \mathrm{mM}$ glucose but no albumin [15]. The gel-filtered platelets were kept in capped polystyrene tubes at room temperature until the start of the incubation. Final platelet concentrations were in the range $(1.5-2.0) \cdot 10^{11}$ cells $\cdot 1^{-1}$.

\section{Incubation conditions}

The gel-filtered platelets were incubated in siliconized glass cuvettes at $37^{\circ} \mathrm{C}$ and stirred at $900 \mathrm{rpm}$. Platelet functions were initiated with 0.2 $\mathrm{U} \cdot \mathrm{ml}^{-1}$ (final concentration) of bovine $\alpha$-thrombin (Roche, Basel, Switzerland), dialyzed against glucose-free and albumin-free Tyrode's solution for $24 \mathrm{~h}$ at $4^{\circ} \mathrm{C}$ and stored at $1000 \mathrm{NIH}$ units. $\mathrm{ml}^{-1}$ at $-80^{\circ} \mathrm{C}$ ). At the times indicated, ATP resynthesis was abruptly blocked by a mixture of 2-deoxy-D-glucose (Merck, Darmstadt, F.R.G.), D-gluconic acid-1,5-lactone (gluconolactone, Sigma, St. Louis, U.S.A.) and antimycin A (Boehringer, Mannheim, F.R.G.), in final concentrations of $45 \mathrm{mM}, 10 \mathrm{mM}$ and $8.3 \mathrm{mg} \cdot 1^{-1}$, respectively. These agents inhibit glycolysis, glycogenolysis and mitochondrial respiration, respectively $[13,14]$, and block lactate production and mitochondrial $\mathrm{O}_{2}$ uptake within $5 \mathrm{~s}$, as confirmed by measurements of lactate production and $\mathrm{O}_{2}$ consumption [14].

In a number of experiments, the metabolic ATP-ADP pool was lowered by incubating the labeled platelet-rich plasma with $1 \mathrm{mM} \mathrm{KCN}$ for $10 \mathrm{~min}\left(37^{\circ} \mathrm{C}\right)$ to inhibit the catalase activity [16], followed by an incubation with $300 \mu \mathrm{M} \mathrm{H}_{2} \mathrm{O}_{2}$ (Baker, Deventer, The Netherlands) for $15 \mathrm{~min}$ $\left(37^{\circ} \mathrm{C}\right)$. The platelets were isolated subsequently by gel filtration according to the procedure described above. Throughout the experiments, cell lysis was minimal $(3.8 \pm 0.4 \%, n=5$ on the basis of the extracellular appearance of lactate dehydrogenase).

\section{Analysis of metabolic parameters}

At different times, samples of cell suspension were collected and mixed with 2 vol. of freshly prepared EDTA/ethanol (10 mM EDTA in $86 \%$ ethanol, $0^{\circ} \mathrm{C}$ ) for analysis of ethanol-soluble ${ }^{3} \mathrm{H}$ labeled adenine nucleotides and derivatives, as outlined in detail elsewhere [14]. This method gives an accurate reflection of the absolute amounts of metabolic ATP and ADP, and is not disturbed by actin-bound ADP (which is insoluble in ethanol) or non-metabolic granular ATP-ADP (which remain unlabeled). The adenylate energy charge $((\mathrm{ATP}+1 / 2 \mathrm{ADP}) /(\mathrm{ATP}+\mathrm{ADP}+\mathrm{AMP}))$ [17] was calculated from the ${ }^{3} \mathrm{H}$-radioactivity in ATP, ADP and AMP. The absolute amount of metabolic ATP was determined in both untreated and $\mathrm{H}_{2} \mathrm{O}_{2}$-treated gel-filtered platelets (see below); under identical conditions, about $80 \%$ of total radioactivity was found in ATP. On this basis, the ${ }^{3} \mathrm{H}$-radioactivity in ATP and ADP was recalculated into absolute amounts and expressed as ATP equivalents (ATPeq), which denote the energy yield of the conversion of ATP to ADP [17]. The energy content is defined as the amount of energy stored in metabolic ATP and ADP, and is expressed as $\mu$ mol ATPeq $/ 10^{11}$ platelets. The absolute amounts of metabolic ATP and ADP were assayed by separating the cytosolic pool from the granular pool by controlled digitonin-induced cell damage followed by centrifugation through a discontinuous phthalate layer, as described elsewhere [18]. Immediately before the digitonin treatment, $8 \mathrm{mM}$ EDTA (final concentration) was added to the gel- 
filtered platelets in order to prevent hydrolysis of ATP and ADP after cell disruption. Both cytosolic and granular fractions were analyzed for ethanolsoluble ATP and ADP by adding 2 vol. of $10 \mathrm{mM}$ EDTA in $86 \%$ ethanol $\left(0^{\circ} \mathrm{C}\right)$ and measuring ATP and ADP with the luciferin-luciferase technique [18] in a Packard Pico-lite luminometer. The data were corrected for non-lyzed cells (based on lactate dehydrogenase) and for nonspecific lysis of dense granules (based on $\left[{ }^{14} \mathrm{C}\right]$ serotonin). The respective coefficients of variation for ATP and ADP were 9 and 11\% for the granular fraction and 9 and 5\% for the cytosolic fraction $(n=8)$. Note that the granule fractions also contain metabolic ATP and ADP localized in the mitochondria (less than $3 \%$ of total metabolic ATP and ADP, Ref. 19).

\section{Analysis of functional parameters}

Shape change was monitored in a Payton Dual Channel Aggregometer (Payton, Scarborough, Canada). Aggregation was measured by two techniques; first, by measuring the change in light transmission in the aggregometer (designated as optical aggregation), and second, by measuring the disappearance of single platelets according to a modification of the method described by Frojmovic et al. [20] (designated as single platelet disappearance). For the last-mentioned procedure, samples were collected from the aggregating suspension and immediately mixed with 9 vol. of 0.5\% glutaraldehyde (Fluka, Buchs, Switzerland) in phosphate-buffered saline (15 mM sodium phosphate; $\mathrm{pH} 7.25,4^{\circ} \mathrm{C}$; filtered through a 0.22 $\mu \mathrm{m}$ Milliporefilter). $150-\mu 1$ samples were then further diluted in $10 \mathrm{ml}$ phoshate-buffered saline and immediately thereafter analyzed in a Platelet Analyzer 810 (Baker Instruments, Allentown, U.S.A.) with apertures set between 3.2 and 16 $\mu \mathrm{m}^{3}$. In an unstimulated suspension, $92.5 \pm 1.0 \%$ (mean \pm S.E., nine donors) of total platelets fell within these settings. Control studies were performed in order to determine how effective this procedure was in stopping aggregation and preventing deaggregation. The same results were obtained when the glutaraldehyde solution contained an additional $4 \mu \mathrm{M}$ prostaglandin $\mathrm{E}_{1}$ (Upjohn, Kalamazoo, U.S.A.) and $10 \mathrm{mM}$ theophylline (Sigma, St. Louis, U.S.A.) which are known to inactivate the platelets by raising the cells' cyclic-
3',5'-AMP content [21]. Furthermore, the presence of $2 \mathrm{mM}$ Gly-Pro-Arg-Pro (UCB, Brussels, Belgium), which inhibits aggregation by interfering with fibrinogen binding [22], did not change the results. Aggregates collected in 9 vol. of glutaraldehyde remained stable for at least $5 \mathrm{~h}$, indicating that deaggregation was minimal. This procedure, therefore, offers an accurate means to measure the disappearance of single platelets in an aggregating suspension.

The three secretion responses were monitored by measuring the extracellular appearance of markers, each specific for one class of secretory granules. These were $\left[{ }^{14} \mathrm{C}\right]$ serotonin, $\beta$-thromboglobulin and $N$-acetyl- $\beta$-D-glucosaminidase (EC 3.2.1.30) for dense, $\alpha$ - and acid hydrolase-containing granules, respectively. Samples of cell suspension were collected in 0.15 vol. of $1.035 \mathrm{M}$ formaldehyde in saline $\left(0^{\circ} \mathrm{C}\right)$. After centrifugation $\left(10000 \times g, 1 \mathrm{~min}, 4^{\circ} \mathrm{C}\right)$ the supernatants were analyzed for $\left[{ }^{14} \mathrm{C}\right]$ serotonin (measured according to standard procedures), $\beta$-thromboglobulin (measured by radioimmunoassay using the kit of Amersham International, U.K.) and $N$-acetyl- $\beta$ $D$-glucosaminidase (measured spectrophotometrically [14]). All studies were carried out in the presence of $3 \mu \mathrm{M}$ imiprmaine (Geigy, Basel, Switzerland) to prevent reuptake of serotonin into the platelets. Secretion was expressed as a percentage of the maximal secretable amount of marker as obtained with $5 \mathrm{U} \cdot \mathrm{ml}^{-1}$ thrombin after 5 min incubation at $37^{\circ} \mathrm{C}$ in the absence of metabolic inhibitors.

\section{Results}

\section{Energy depletion during aggregation and secretion}

Upon stimulation with $0.2 \mathrm{U} \cdot \mathrm{ml}^{-1}$ thrombin, the platelets changed shape in a few seconds, aggregated, and in about $2.5 \mathrm{~min}$ secreted 95,85 and $55 \%$ of the releasable contents of $\left[{ }^{14} \mathrm{C}\right]-$ serotonin, $\beta$-thromboglobulin and $N$-acetyl- $\beta$-Dglucosaminidase, respectively. Single platelet disappearance was already complete in about $45 \mathrm{~s}$, while optical aggregation required 4-5 $\mathrm{min}$ to reach a full extent. These functional responses were accompanied by a $25 \%$ fall in energy content (Fig. 1).

The addition of a mixture of 2-deoxy-D-glucose, 


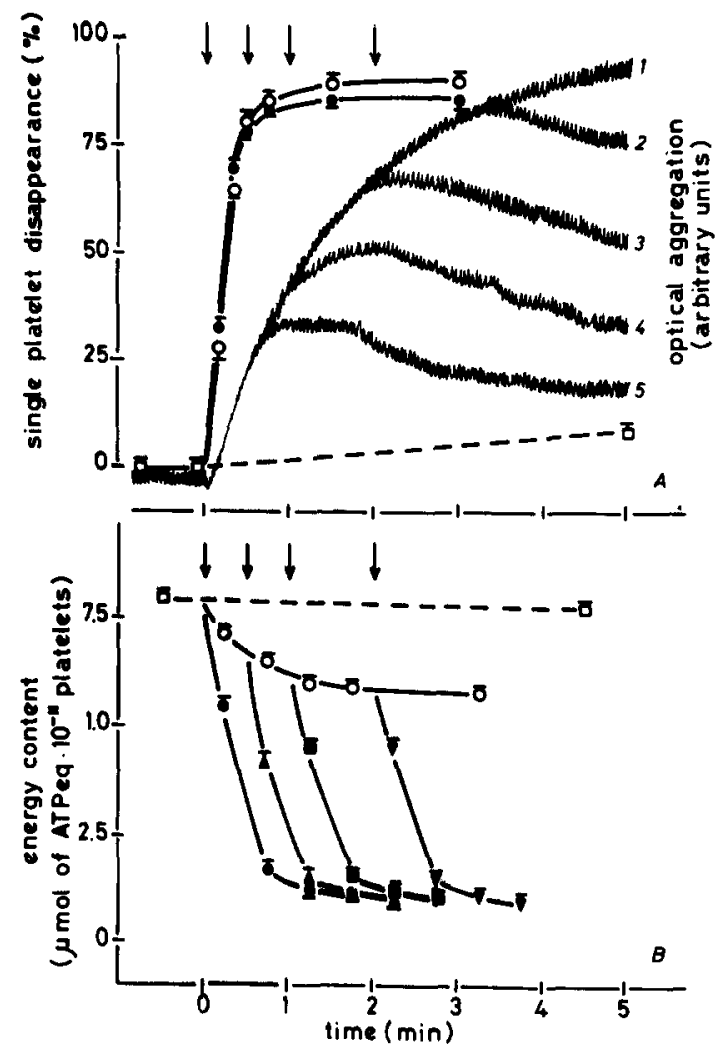

Fig. 1. Effect of energy exhaustion on platelet responses. $\left[{ }^{3} \mathrm{H}\right]$ Adenine-labeled gel-filtered platelets were incubated in the presence of $1 \mathrm{mM}$ glucose and stimulated with $0.2 \mathrm{U} \cdot \mathrm{ml}^{-1}$ thrombin (final concentration) at time zero. Parallel samples were used for analysis of single platelet disappearance $(\mathrm{O}-0)$ and optical aggregation (A) and for analysis of energy content (B) and secretion parameters (data not shown). Energy exhaustion was induced by adding a mixture of 2-deoxy-D-glucose, gluconolactone and antimycin $A$ at $1 \mathrm{~s}(e$, curve Nr. 5), 30 s ( 4 , curve Nr. 4) $60 \mathrm{~s}(\mathbf{1}$, curve Nr. 3) and 120 $s(\nabla$, curve $\mathrm{Nr}, 2)$ as indicated by the arrows. In the control suspension, no inhibitors were added $(\mathrm{O}-\mathrm{O}$; curve $\mathrm{Nr}$. 1). The percentage of single platelets and the energy content of the stimulated platelets were compared with the values found in resting suspensions ( $\square$ - . . - - The data on single platelet disappearance in suspensions $2-4$ have been omitted for the sake of clarity. Results are means \pm S.E. from five experiments.

gluconolactone and antimycin $\mathrm{A}$ at various stages after stimulation with thrombin led to a rapid exhaustion of the platelet energy content. Immediately after stimulation, as well as at later stages of aggregation and secretion, the fall in $\left[{ }^{3} \mathrm{H}\right] \mathrm{ATP}$ and ADP followed the same pattern and indicated that within $30 \mathrm{~s}$ the energy content was reduced to about $3 \mu \mathrm{mol}$ of ATPeq $/ 10^{11}$ cells. The inhibitors also affected optical aggregation, which was interrupted after a lag time of about $90 \mathrm{~s}$ and followed by a slight deaggregation (Fig. 1A). The arrest of optical aggregation correlated with an energy content of $1.0-1.5 \mu \mathrm{mol}$ of ATPeq $/ 10^{11}$ platelets. In contrast, neither single platelet disappearance (Fig. 1A) nor secretion of $\left[{ }^{14} \mathrm{C}\right]$ serotonin, $\beta$-thromboglobulin and $N$-acetyl- $\beta$-D-glucosaminidase (not shown) were affected considerably by the metabolic inhibitors. These responses, however, were much faster than optical aggregation and were completed to a considerable extent before the energy content was depleted. Therefore, alternative methods were sought in order to deplete the cell energy content more rapidly.

\section{Energy depletion in $\mathrm{H}_{2} \mathrm{O}_{2}$-treated platelets}

In previous studies, Holmsen and Robkin [16] showed that the content of metabolic ATP can be reduced sharply by pretreating platelets with $\mathrm{H}_{2} \mathrm{O}_{2}$. Under those conditions, the cells maintain a high adenylate energy charge and remain fully responsive to platelet-stimulating agents. Table I shows that pretreatment of platelet-rich plasma with $\mathrm{H}_{2} \mathrm{O}_{2}$ in the presence of the catalase inhibitor cyanide followed by gel filtration, led to a $45 \%$ fall in cytosolic ATP, whereas cytosolic ADP, granular ATP and ADP, and the adenylate energy charge remained unaffected. This treatment reduced the cell energy content by $45 \%$ to $4.5 \pm 1.0 \mu \mathrm{mol}$ of ATPeq $/ 10^{11}$ platelets (mean \pm S.E., $n=5$ ) without affecting single platelet disappearance, shape change and optical aggregation (Fig. 2A and B) and the three secretion responses (Fig. $2 \mathrm{C}$ and $\mathrm{D}$ ). There was no difference between the secretion of the three markers in $\mathrm{H}_{2} \mathrm{O}_{2}$-treated and untreated suspensions (at $2.5 \mathrm{~min}$ after stimulation with 0.2 $\mathrm{U} \cdot \mathrm{ml}^{-1}$ thrombin, $P>0.10, n=5$ ).

As in untreated cells, the addition of the metabolic inhibitors at various stages of aggregation and secretion reduced the energy content of $\mathrm{H}_{2} \mathrm{O}_{2}$-treated platelets, but the fall in $\left[{ }^{3} \mathrm{H}\right] \mathrm{ATP}$ and ADP was slightly slower than in normal platelets. Nevertheless, an arbitrary value of 3 $\mu \mathrm{mol}$ of ATPeq $/ 10^{11}$ cells was now reached within $15 \mathrm{~s}$, compared to the $30 \mathrm{~s}$ in untreated platelets. The $\mathrm{H}_{2} \mathrm{O}_{2}$ treatment did not change the sensitivity of optical aggregation for metabolic blockade, but the time between addition of the inhibitors and 
TABLE I

\section{COMPARTMENTATION OF ATP AND ADP IN NORMAL AND $\mathrm{H}_{2} \mathrm{O}_{2}$-TREATED GEL-FILTERED PLATELETS}

Data on ATP and ADP are expressed as $\mu \mathrm{mol} / 10^{11}$ platelets (means \pm S.E.) and reflect ethanol-soluble adenine nucleotides. Differences between normal and $\mathrm{H}_{2} \mathrm{O}_{2}$-treated platelets were analyzed by Student's $t$-test and considered non-significant (n.s.) at $P>0.05$. The adenylate energy change (AEC) was calculated from the ${ }^{3} \mathrm{H}$-radioactivity in ATP, ADP and AMP.

\begin{tabular}{|c|c|c|c|c|c|c|c|}
\hline & \multicolumn{2}{|l|}{ Total } & \multicolumn{2}{|l|}{ Cytosol } & \multicolumn{2}{|l|}{ Granules } & \multirow[t]{2}{*}{$\mathrm{AEC}$} \\
\hline & ATP & ADP & ATP & ADP & ATP & ADP & \\
\hline Control $(n=13)$ & $6.51 \pm 0.39$ & $2.86 \pm 0.33$ & $3.68 \pm 0.33$ & $0.58 \pm 0.18$ & $2.83 \pm 0.28$ & $2.27 \pm 0.33$ & $0.901 \pm 0.006$ \\
\hline $\mathrm{H}_{2} \mathrm{O}_{2}$-treated $(n=5)$ & $4.26 \pm 0.52$ & $3.06 \pm 0.34$ & $2.07 \pm 0.47$ & $0.32 \pm 0.14$ & $2.19 \pm 0.24$ & $2.74 \pm 0.23$ & $0.892 \pm 0.005$ \\
\hline$P$ & $<0.01$ & n.s. & $<0.025$ & n.s. & n.s. & n.s. & \\
\hline
\end{tabular}

arrest of optical aggregation was reduced to about $60 \mathrm{~s}$, compared to $90 \mathrm{~s}$ in untreated cells. As in untreated platelets, the arrest of optical aggregation coincided with an energy content of $1-1.5$ $\mu \mathrm{mol}$ of ATPeq $/ 10^{11}$ platelets (Fig. $2 \mathrm{~A}$ ). In contrast to normal platelets, the inhibitor mixture greatly interfered with the secretion responses in $\mathrm{H}_{2} \mathrm{O}_{2}$-treated cells. When the inhibitors were ad-
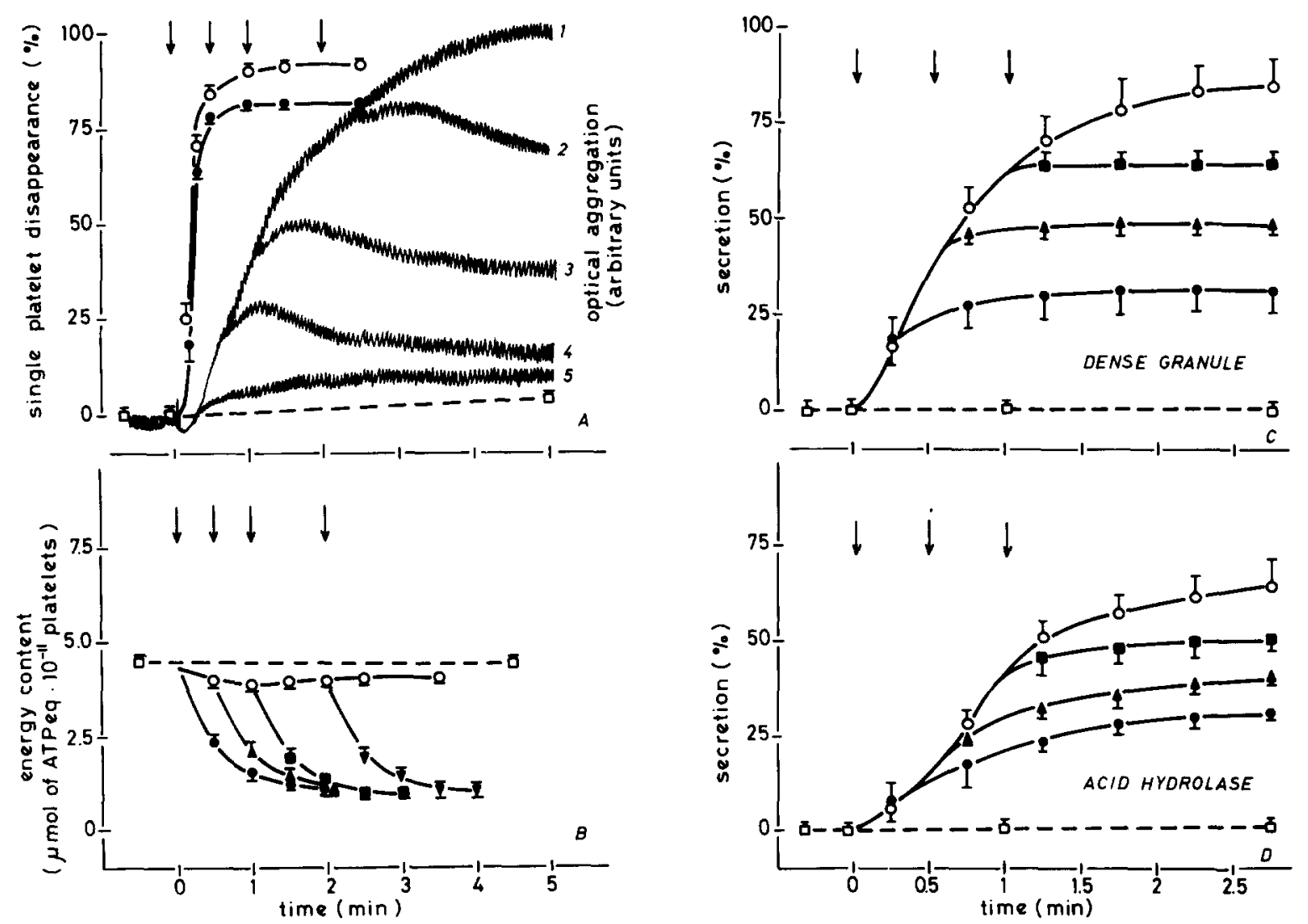

Fig. 2. Effect of energy exhaustion on $\mathrm{H}_{2} \mathrm{O}_{2}$-treated platelets. The experiments were performed as described for Fig. 1, but using platelets pretreated with $\mathrm{H}_{2} \mathrm{O}_{2}$. In addition, the data on $\left[{ }^{14} \mathrm{C}\right]$ serotonin (C) and $N$-acetyl- $\beta$-D-glucosaminidase (D) secretion (expressed as percentage of maximal secretable) are shown. Data on $\beta$-thromboglobulin secretion were intermediate between $\left[{ }^{14} \mathrm{C}\right]$ serotonin and $N$-acetyl- $\beta$-D-glucosaminidase secretion (not shown). In $\mathrm{C}$ and $\mathrm{D}$ the percentage of secretion in suspension 2 has been omitted for the sake of clarity. Results are means \pm S.E. from five experiments. 
ded at $1 \mathrm{~s}$ after thrombin, secretion of $\left[{ }^{14} \mathrm{C}\right]-$ serotonin (Fig. 2C), $\beta$-thromboglobulin (not shown) and $N$-acetyl- $\beta$-D-glucosaminidase (Fig. $2 D)$ at first proceeded normally. After about $15 \mathrm{~s}$, secretion slowed down and eventually secretion of $\left[{ }^{14} \mathrm{C}\right]$ serotonin, $\beta$-thromboglobulin and the acid hydrolase stopped completely after about $75 \mathrm{~s}, 90$ $\mathrm{s}$ and $2.5 \mathrm{~min}$, respectively. At $2.5 \mathrm{~min}$ after stimulation, all three secretion responses were inhibited by $55 \%$, compared to $20 \%$ in normal cells. Arrest of secretion coincided with an energy content of about $2.0,1.5$ and $1.0 \mu \mathrm{mol}$ of ATPeq $/ 10^{11}$ platelets, for $\left[{ }^{14} \mathrm{C}\right]$ serotonin, $\beta$-thromboglobulin and the acid hydrolase, respectively. Depletion of the energy content at later stages decreased the lag times. For instance, when $\left[{ }^{14} \mathrm{C}\right]$ serotonin secretion was about $60 \%$ complete, the response to metabolic blockade was almost immediate. Similarly, at $40 \% N$-acetyl- $\beta$-D-glucosaminidase secretion, this response stopped within $60 \mathrm{~s}$ following metabolic arrest. At this stage, arrest of $\left[{ }^{14} \mathrm{C}\right]$ serotonin, $\beta$ thromboglobulin and $N$-acetyl- $\beta$-D-glucosaminidase secretion was paralleled by respective energy contents of 2.5, 2.0 and $1.0 \mu \mathrm{mol}$ of ATPeq $/ 10^{11}$ platelets.

The $\mathrm{H}_{2} \mathrm{O}_{2}$ treatment also made the single platelet disappearance sensitive to metabolic arrest. This effect, however, was only observed when the inhibitors were added as soon as $1 \mathrm{~s}$ after stimulation with thrombin (Fig. 2A). The initial rate of single platelet disappearance was not significantly affected by the inhibitors $(P>0.05, n=10$, at 15 $s$ after stimulation). Final extent, however, was decreased by almost $10 \%$ at $1 \mathrm{~min}$ after stimulation $(P<0.001, n=10)$.

\section{Partial energy exhaustion}

Fig. 3 illustrates the secretion of $\left[{ }^{14} \mathrm{C}\right]$ serotonin by platelets with an only partially depleted energy content. $\mathrm{H}_{2} \mathrm{O}_{2}$-treated platelets, preincubated with $25 \mathrm{mM}$ glucose, were stimulated with thrombin $\left(0.2 \mathrm{U} \cdot \mathrm{ml}^{-1}\right)$. Immediately thereafter, the inhibitor mixture was added, in which the 2-deoxy-Dglucose concentration was lowered in order to obtain a final concentration of $20 \mathrm{mM}$ in the platelet suspension. This resulted in a 2-deoxy-Dglucose/glucose ratio of 0.8 , compared to a ratio of $\mathbf{4 5}$ when complete exhaustion was required (Fig. 2 ). This treatment only partially inhibited glyco-

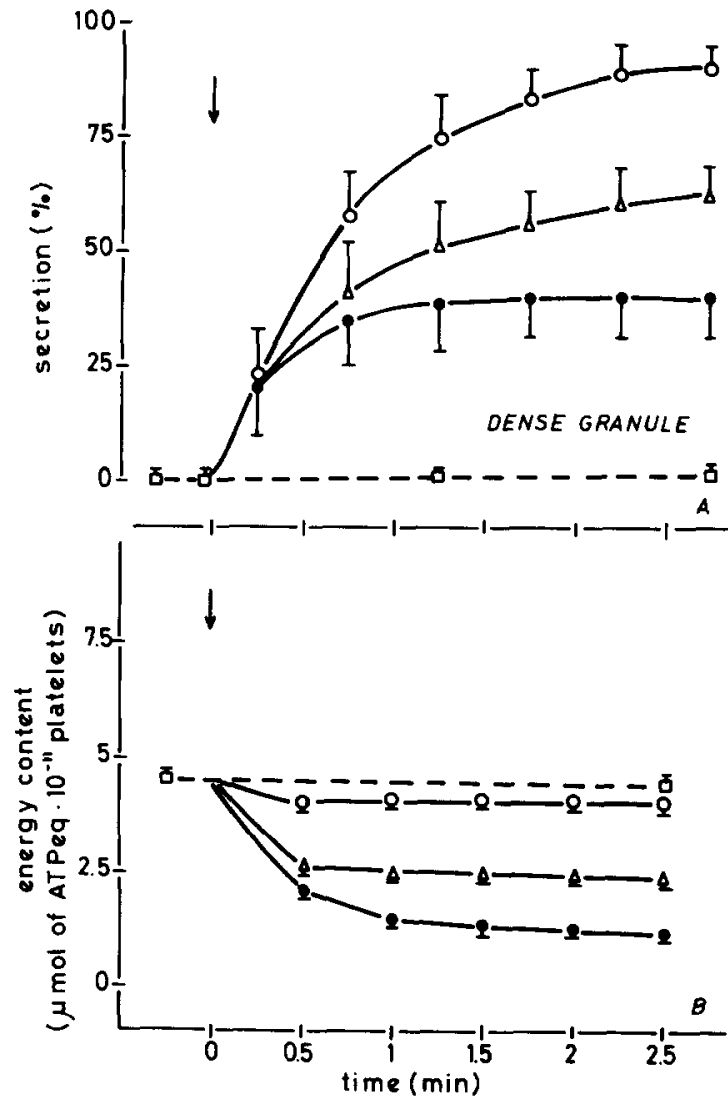

Fig. 3. Partial energy exhaustion and its effect on dense granule secretion. Secretion of $\left[{ }^{14} \mathrm{C}\right]$ serotonin (expressed as percentage of maximal secretable) and energy content in platelets stimulated with $0.2 \mathrm{U} \cdot \mathrm{ml}^{-1}$ thrombin (final concentration) without metabolic blockade $(\mathrm{O}-\mathrm{O})$ and in the presence of the mixture of 2-deoxy-D-glucose, gluconolactone and antimycin A, added $1 \mathrm{~s}$ after thrombin $(\Delta ; \bullet)$. In one series, complete energy exhaustion was induced by using a final 2-deoxy-D-glucose/ glucose ratio of 45 , similar to the experiments shown in Figs. 1 and 2 (-). In the other series, the 2-deoxy-D-glucose/ glucose ratio was 0.8 , thereby only partially exhausting the cell energy content (suspensions in $25 \mathrm{mM}$ glucose, $\Delta-\Delta$ ). The dotted line represents the data from unstimulated suspensions (口- - - - $\square$ ). Data are means \pm S.E. from four experiments.

lytic energy generation and induced incomplete exhaustion of the cell energy content. At $2.5 \mathrm{~min}$ after thrombin addition, the energy content of partially and completely inhibited suspensions was $60 \pm 2 \%$ and $29 \pm 1 \%$ (means \pm S.E., $n=4$ ) of values in uninhibited platelets (Fig. 3B). Under the same conditions, the secretion of $\left[{ }^{14} \mathrm{C}\right]$ serotonin was completed at $60 \pm 7 \%$ and $38 \pm 8 \%$ (means \pm 
S.E., $n=4$ ) of maximal secretable amounts, respectively. Thus, dense granule secretion and energy content vary in parallel, which supports the concept of a close coupling between secretion and metabolic energy. Similar findings were obtained for $\beta$-thromboglobulin and $N$-acetyl- $\beta$-D-glucosaminidase (data not shown).

\section{Discussion}

Unstimulated human platelets produce and consume metabolic ATP at a rate of 4-6 $\mu \mathrm{mol}$ of ATPeq $/$ min per $10^{11}$ platelets $[14,23]$. On the basis of cell volume, this number is close to the values found in human neutrophils [24] and human lymphocytes [25], but is about 2.5-fold higher than in rabbit reticulocytes [26] and even more than 150-times higher than in rabbit [26] and human [27] erythrocytes. Compared to other cells, therefore, platelets have a high ATP turnover, which is the more puzzling since platelets lack a number of energy-consuming processes that are common in many other cells, such as protein synthesis, biosynthesis of complex carbohydrates, etc. One has hypothesized that the high ATP turnover in resting platelets is related to the specific responses that platelets perform upon stimulation, which are all extremely fast and are completed within 1-2 min. In this respect, the role of actin is of special interest, since it is present in high quantities and undergoes a rapid polymerization-depolymerization cycle, accompanied by hydrolysis of ATP. The rate of ATP consumption in this actin treadmill has been estimated at $1.8 \mu \mathrm{mol}$ of ATPeq $/ \mathrm{min}$ per $10^{11}$ platelets [28], which equals as much as $40 \%$ of the energy consumption in the resting platelet. This finding has led to the suggestion that resting platelets build up a supply of energy that is sufficient for the support of platelet responses once the cells are stimulated [3,11]. Consequently, the execution of those responses would not depend on simultaneous ATP catabolism.

Experimentally, it has been difficult to distinguish between a role for energy in the maintenance of responsiveness and in the execution of aggregation and secretion. In 1977, Holmsen and Robkin [16] showed that an adenylate energy charge of 0.88 or more was required for optimal responsiveness, whereas the metabolic ATP con- tent was less relevant. Our observations are in line with this concept: aggregation and secretion are normal in cells with an energy charge of 0.9 and an energy content of 8 (normal cells) or 4.5 $\left(\mathrm{H}_{2} \mathrm{O}_{2}\right.$-treated cells) $\mu \mathrm{mol}$ of ATPeq $/ 10^{11}$ platelets. The present data demonstrate that the execution phase of these responses also requires energy. Furthermore, there are no stages in these responses in which energy is not required. Experiments at low temperature $[29,30]$ and in glucosedepleted medium [31] have shown that the thrombin-receptor interaction occurs in the absence of energy metabolism, but that aggregation and secretion only take place when energy generation is restored. The execution of these responses is accompanied by a rapid phosphorylation of myosin light chain [32] and sudden alterations in the metabolism of phosphatidylinositol and its polyphosphates [33]. Both processes depend on energy, and their time-courses suggest that most of the energy is required during the first few seconds after stimultion. Our data show that also the later stages of aggregation and secretion depend on energy, possibly because at those stages other energy-dependent processes, for example contractile activity [32], are equally important. Platelet aggregation is thought to be mediated via bridges consisting of divalent cations [34], fibrinogen [34] and thrombospindin [35]. These proteins are liberated from the $\alpha$-granules during secretion. Under our experimental conditions, optical aggregation of normal platelets is interrupted after the secretion from the $\alpha$-granules is completed (Fig. 1). Under those conditions optical aggregation is no longer dependent on secretion, and its susceptibility for metabolic blockade indicates that, for the formation of large aggregates, continuous energy support is required. In contrast, single platelet disappearance, which is probably also a manifestation of the fibrinogen receptor, is not affected by the inhibitors to a great extent. Although this would suggest that this process does not require energy, this finding may also result from shortcomings in the experimental procedure. Single platelet disappearance is a very rapid process and is almost completed before the metabolic inhibitors have exhausted the cell energy content. The question as to the energy need of early aggregate formation, therefore, remains unanswered and requires fur. 
ther experiments, in which fibrinogen binding, aggregate formation and cell-cell contact activation are measured separately.

Optical aggregation and secretion were not affected by the metabolic inhibitors until the energy content had dropped below about $3 \mu \mathrm{mol}$ of ATPeq $/ 10^{11}$ platelets. Apparently, these functions benefited from the energy stored in metabolic ATP and ADP. This is in agreement with previous studies that demonstrated normal platelet responses after ATP resynthesis was rapidly blocked [8]. Complete metabolic blockade does not change the initial velocity, whereas the extent of secretion is significantly reduced. This finding is in conflict with the exponential model for dense granule secretion developed by Detwiler and Feinman [36], in which the rate constant $k_{2}$ is independent of the extent of secretion.

An alternative way to prevent ATP catabolism has been demonstrated by Ashby et al. [37] with the AMP-deaminase inhibitor coformycin. Under our experimental conditions, preincubation of platelets for $6 \mathrm{~h}$ with $200 \mu \mathrm{M}$ coformycin (a gift from Dr. Martin Black, Warner-Lambert Pharmaceutical Research Division, Ann Arbor, U.S.A.) led to an almost complete inhibition of AMPdeamination in the absence of metabolic inhibitors. Upon addition of the metabolic inhibitors, however, the cell energy content was depleted almost as rapidly as in the absence of coformycin. Initially, $\left[{ }^{3} \mathrm{H}\right] \mathrm{AMP}$ increased to $2.0 \pm 0.1 \mu \mathrm{mol} /$ $10^{11}$ platelets (mean \pm S.E., $n=4$ ) after which $\left[{ }^{3} \mathrm{H}\right] \mathrm{IMP}$ started to accumulate, despite the presence of coformycin. The effects of metabolic inhibition on the measured platelet responses were identical in the presence and absence of coformycin.

The three secretion responses have been reported to decrease in energy dependence in the order acid hydrolase secretion, $\alpha$-granule secretion and dense granule secretion [7,9]. Those findings were based on a different susceptibility to pretreatment with metabolic inhibitors. However, the interpretation of these data is hampered by differences in secretion velocity, making the slowest response the most sensitive to decreasing energy availability. Our data do not reveal such differences. In fact, during the early stages of secretion, the coupling with energy appears weaker for acid hydrolase secretion than for dense granule secretion with intermediate values for $\alpha$-granule secretion. Apparently, the time point at which energy availability is reduced (either before or after initiation of secretion) determines which secretion response depends most on energy. In particular, lysosomal granule secretion is highly susceptible to metabolic blockade when energy becomes exhausted prior to induction [4,9]. In contrast, when secretion is induced under optimal conditions and energy supply becomes exhausted thereafter, this response is less sensitive than both other secretion responses. This opens the possibility that the role of energy in the three secretion responses is different in the induction phase than it is in the execution phase.

\section{Acknowledgement}

These investigations were supported in part by the Netherlands Foundation for Medical Research FUNGO (Grant No. 13-30-36).

\section{References}

1 McElroy, F.A., Kinlough-Rathbone, R.L., Ardlie, N.G., Packham, M.A. and Mustard, J.F. (1971) Biochim. Biophys. Acta 253, 64-77

2 Fukami, M.H., Holmsen, H. and Salganicoff, L. (1976) Biochim. Biophys. Acta 444, 633-643

3 Holmsen, H. (1977) in Platelets and Thrombosis (Mills, D.C.B. and Pareti, F.I., eds.), pp. 45-62, Academic Press, London

4 Akkerman, J.W.N. and Holmsen, H. (1981) Blood 57, 956-966

5 Mürer, E.H. (1968) Biochim. Biophys. Acta 162, 320-326

6 Kattlove, H. (1974) Am. J. Physiol. 226, 325-329

7 Holmsen, H., Robkin, L. and Day, H.J. (1979) Biochem. J. $182,413-419$

8 Akkerman, J.W.N., Holmsen, H. and Driver, H.A. (1979) FEBS Lett. 100, 286-290

9 Holmsen, H., Kaplan, K.L. and Dangelmaier, C.A. (1982) Biochem. J. 208, 9-18

10 Chaudry, A.A., Sagone, A.L., Jr., Metz, E.N. and Balcerzak, S.P. (1973) Blood 41, 249-258

11 Holmsen, H. (1975) in Biochemistry and Pharmacology of Platelets (Elliot, K. and Knight, J., eds.), pp. 175-205, Ciba Found. Symp. 35, Elsevier Amsterdam

12 Reimers, H-J., Packham, M.A., Kinlough-Rathbone, R.L. and Mustard, J.F. (1973) Br. J. Haematol. 25, 675-689

13 Holmsen, H. and Robkin, L. (1980) Thromb. Haemostasis $42,1460-1472$

14 Akkerman, J.W.N., Gorter, G., Schrama, L. and Holmsen, H. (1983) Biochem. J. 210, 145-155 
15 Walsh, P.N. (1972) Br. J. Haematol. 22, 205-217

16 Holmsen, H. and Robkin, L. (1977) J. Biol. Chem. 252, 1752-1757

17 Atkinson, D.E. (1977) Cellular Energy Metabolism and its Regulation, pp. 40-50, Academic Press, New York

18 Akkerman, J.W.N., Ebberink, R.H.M., Lips, J.P.M. and Christiaens, G.C.M.L. (1980) Br. J. Haematol. 44, 291-300

19 Holmsen, H., Day, H.J. and Storm, E. (1969) Biochim. Biophys. Acta 186, 254-266

20 Frojmovic, M.M., Milton, J.G. and Duchastel, A. (1983) J. Lab. Clin. Med. 101, 964-976

21 Mills, D.C.B. (1974) in Platelets and Thrombosis (Sherry, S. and Scriabine, A., eds.), pp. 45-67, University Park Press, Baltimore

22 Plow, E.F. and Marguerie, G. (1982) Proc. Natl. Acad. Sci. USA 79, 3711-3715

23 Verhoeven, A.J.M., Mommersteeg, M.E. and Akkerman, J.W.N. (1984) Biochem. J., in the press

24 Borregaard, N. and Herlin, T. (1982) J. Clin. Invest. 70, $550-557$

25 Roos, D. and Loos, J.A. (1972) Exp. Cell Res. 77, 121-126

26 Siems, W., Müller, M., Dundey, R., Holzhütter, H.-G., Rathmann, J. and Rapoport, S.M. (1982) Eur. J. Biochem. 124, $567-576$
27 Keitt, A.S. and Bennett, D.C. (1966) Am. J. Med. 41, 762-785

28 Daniel, J.L., Molish, I.R., Salganicoff, L. and Holmsen, H. (1979) in Motility in Cell Function (Pepe, F.A., Sanger, D.J. and Nachmias, V.T. eds.), pp. 459-463, Academic Press, New York

29 Mürer, E.H. (1972) Biochim. Biophys. Acta 261, 435-443

30 Wallace, W.C. and Bensusan, H.B. (1980) J. Biol. Chem. 255, 1932-1937

31 Kinlough-Rathbone, R.L., Packham, M.A. and Mustard, J.F. (1972) J. Lab. Clin. Med. 80, 247-255

32 Daniel, J., Molish, I.R., Holmsen, H. and Salganicoff, L. (1981) Cold Spring Harbor Conf. Cell Prolif. 8, 913-928

33 Lloyd, J.V. and Mustard, J.F. (1974) Br. J. Haematol. 26, 243-253

34 Peerschke, E.I., Zucker, M.B., Grant, R.A., Egan, J.J. and Johnson, M.M. (1980) Blood 55, 841-847

35 Jaffe, E.A., Leung, L.L.K., Nachman, R.L., Levin, R.I. and Mosher, D.F. (1982) Nature 295, 246-248

36 Detwiler, T.C. and Feinman, R.D. (1973) Biochemistry 12, 282-289

37 Ashby, B., Wernick, E. and Holmsen, H. (1983) J. Biol. Chem. 258, 321-325 